\title{
Comparative Efficacy of Insecticidal Plants on the Management of Groundnut Bruchid
}

\section{(Caryedon Serratus)}

\author{
Simon Idoko Okweche \\ Department of Forestry and Wildlife Resources Management, University of Calabar, PMB \\ 1115, Calabar, Nigeria. \\ Phone: +2347034967125 \\ Sylvia Bassey Umoetok \\ Department of Crop Science, University of Calabar, PMB 1115, Calabar, Nigeria \\ Phone: +2347034966700 \\ Ukatu, Patrick Odey \\ Department of Crop Science, University of Calabar, PMB 1115, Calabar, Nigeria \\ Received: March 9, 2016 Accepted: March 21, 2016 Published: June 31, 2016 \\ doi:10.5296/jas.v4i3.9681ＵRL: http://dx.doi.org/10.5296/jas.v4i3.9681
}

\begin{abstract}
Laboratory study was conducted to determine the efficacy of insecticidal plant extracts Azadirachta indica A. (Juss), Lantana camara L. (Verbenaceae), Eupatorium odoratum L. (Asteraceae), Tephrosia vogelii Hook, Afromomum melegueta K.M. (Schumann) and Ocimum gratissimum (L) leaves against groundnut bruchid beetle (Caryedon serratus), and a synthetic insecticide (Cypermethrin) (10EC)) under ambient condition of temperature and relative humidity $\left(30^{\circ} \mathrm{C}\right.$ and $\left.72 \%\right)$. One hundred grams of shelled groundnut was weighed into jute bags and treated with powders of the insecticidal plants. Both treated and untreated bags of groundnut were then infested with newly emerged adult of $C$. serratus (20 per bag) and covered. The experiment was laid out in Completely Randomized Design (CRD) and replicated four times. Parameters assessed included number of egg oviposited, number of eggs hatched (eclosion) and number of adults that emerged from each treatment, total developmental period (egg - adult), sex ratio of the emerged adults and finally percentage germination of the treated seeds. Data collected were analyzed using analysis of variance and treatment means were separated using Duncan multiple range tests at $\mathrm{P} \leq 0.05$ level of significance. Results showed that A. indica, L. camara, T. vogelli, A. melegueta and $O$. gratissimum treated seeds significantly recorded lowest mean number of eggs, reduced
\end{abstract}


damage by $C$. serratus and increased germination percentage compared with E. odoratum and control. In conclusion, A. indica, L. camara, T. vogelli, A. melegueta and O. gratissimum the potentials as alternatives to synthetic insecticides in the management of $C$. serratus by resource poor farmers.

Keywords: Caryedon serratus, damage, groundnut, germination percentage, Insecticidal

plants, synthetic insecticide

\section{Introduction}

A major arable crop cultivated in the tropical and subtropical regions of the world is the leguminous crop - groundnut (Arachis hypogea) of the family Fabaceae. Groundnut (Arachis hypogea) which is commonly stored as staple for man has several benefits - the grains are cheap source of protein to man (Alabi et al., 2003) and in recent times, largely depends on it because of the rising cost of meat, fish and egg and other protein products. Groundnut is rich in vitamins, minerals and oil. Its other importance is in the livestock industry, fibre production (Rachie, 1985) and restoration of soil fertility/erosion control (Okigbo, 1978). Reasonable losses of between $20-50 \%$ have been reported on stored groundnut due to attack by groundnut bruchid (Caryedon serratus) and may sometimes reach $100 \%$ if not controlled (Alabi et al., 2003). Apart from direct damage to the grains, losses may also occur as a result of contamination with the insect waste materials such as faeces, nitrogenous wastes and exuviae (Emoisairue et al., 2004). Effort has been made by farmers in the management of groundnut bruchid amongst which includes the use of synthetic and non-synthetic insecticides.

Currently, insect control in stored products relies primarily upon the use of gaseous synthetic fumigants and residual insecticides, both of which may pose serious hazards to humans and the environment. Residues of methyl bromide, one of the two synthetic fumigants still used in the disinfestations of stored foods, have been found to exhibit carcinogenic effects in rats (Dansi et al., 1984) Of recent, many researchers have turned to the use of botanicals and plant products in the control of pest due to the hazardous effects of synthetic insecticides on the environment (Omongo, et al., 1997). The protection of stored products by the use of plant materials is a common practice among smallholder farmers in Africa. Repellent, anti-feedant, and insecticidal substances have been identified in a large variety of plant species, long before the "industrial insecticide revolution" in the 1930's and 1940 when compounds such as nicotine and pyrethrum were the only effective insecticides (Mahdi, 2008). Azadirachtin, a component of $A$. indica is presently considered as a promising alternative to synthetic insecticides, and is currently used by developed and developing countries for the control of both field and stored insect pests (Rajapakse et al., 2002; Rajapakse and Ratnasekera, 2009, Okweche, et al., 2013). The aim of the experiment was to investigate the efficacy of A. indica. camara, E. odoratum, T. vogelii against the groundnut bruchid (Caryedon serratus), in comparison it with synthetic insecticide (Cypermethrin) (10EC)).

\section{Materials and methods}

\subsection{Legume Grains}

Shelled groundnut used for the trial was obtained from Abuochiche market in Bekwarra local 
government area of Cross River State and stored in jute bags in the Crop Science Departmental Lab, University of Calabar till when needed.

\subsection{Caryedon serratus}

The method of Ousman et al. (2007) was adopted in the mass production of $C$. serratus. The mass production of $C$. serratus took place in the Crop Science Laboratory, University of Calabar, Nigeria, under ambient temperature and relative humidity $\left(28 \pm 5^{\circ} \mathrm{Cand} 66.6 \%\right)$, respectively. Hundred newly emerged adults of $C$. serratus of mixed sexes (male and female) were obtained from a laboratory stock culture and reared on $100 \mathrm{~g}$ each of A. hypogea in perforated plastic containers and covered with muslin cloth. After one week, when oviposition had been noticed, the parent stocks of $C$. serratus were removed by sieving the grain with a $2.00 \mathrm{~mm}$ sieve. The grains with the oviposited ova were left under laboratory conditions till emergence of F1 progeny. The F1 progenies from the cultures were then used for the experiment.

\subsection{Plant materials}

The plant materials used for this study were collected from forestry plantation of the Department of Forestry and Wildlife Resources Management, University of Calabar. The plant materials were shade-dried for three weeks until a constant weight was maintained. They were ground and sieved into powder using $0.20 \mathrm{~mm}$ mesh sieves preserved in plastic air-tight bottles under refrigeration until needed.

\subsection{Phyto-chemistry of plant materials}

The $5 \mathrm{~g}$ of each powdered plant material was weighed using an electronic weighing balance and mixed in $25 \mathrm{ml}$ of distilled water, steamed for 35 minutes on a bath at $60^{\circ} \mathrm{Cand}$ then filtered using filter paper (Whatman). The filtrates were then centrifuged at $2500 \mathrm{rpm}$ for 15 min, the supernatants were discarded and the residues stored in sterile bottles at $5^{\circ} \mathrm{C}$ according to Harbone (1973). The samples were later tested for alkaloids, glycosides, saponins, reducing sugar, tannins, steroids, resins and acidic compounds.

\subsection{Experimental design}

A total of 32 jars (with diameter $0.09 \mathrm{~m}$, volume $3.69 \mathrm{~m}^{3}$ ) were used for the experiment. Twenty newly emerged $C$. serratus adults of less than 24 hrs old (10 males and 10 females) were introduced into each of the jars containing $30 \mathrm{~g}$ of grains (A. hypogea) containing $1 \mathrm{~g}$ each of the botanicals (A. indica, E. odoratum, L. camara, T. vogelii, A. melegueta, $O$. gratissimum). The Cypermethrin (10EC) was applied at the rate of $0.1 \mathrm{~g}$ per $30 \mathrm{~g}$ of each legume grain which serves as standard control and an untreated jar which serves as control group was set up with the grains and C. serratus with no botanical (experimental control). Each jar was covered with a muslin cloth to allow air movement and prevent insects from escaping. The experiment was laid out in a completely randomised design (CRD) and each treatment was replicated four times at $24 \mathrm{hr}$ intervals and was randomly assigned to positions at a temperature of $26^{\circ} \mathrm{C}$ and relative humidity of $75 \%$. The set up was allowed for four days with daily monitoring.

Data were collected on the total number of egg oviposited, number of eggs hatched (eclosion) 
and number of adults that emerged from each treatment. The total developmental period (egg - adult) and the sex ratio of the emerged adults were also recorded and analyzed using analysis of variance. Germination percentage of the seeds was assessed by placing the seeds in a germination medium and assessed at 5, 7 and 10 days after germination trial. Dead insects in each jar was collected and counted and the percentage insect mortality was calculated thus:

Percent insect mortality $=$ number of dead insects $\mathrm{x} 100$

total number of insects

The results were then subjected to analysis of variance using Statview software and means separated using New Duncan Multiple Range Test (NDMRT) at 5\% level of significance

\section{Results}

The phyto-chemical studies of eight powdered plant materials used in this study indicated that alkaloids were highly present in L. camara, T. vogelii, and A. melegueta; it was also found to be present in low concentrations in A. indica, E. odoratum and O. gratissimum. Similarly, glycosides were found to be abundantly present in O. gratissimum, and highly present in A. indica, A. melegueta while in moderate concentrations in $T$. vogelii and in slightly present in L. camara, and E. odoratum. More so, saponins were present in abundant concentration in A. melegueta, high in $O$. gratissimum, T. vogelii, and E. odoratum while moderately present in A. indica, and L. camara. Tannins were found to be abundantly present in A. melegueta, high in T. vogelii, moderately present in A. indica and L. camara, $O$. gratissimun and E. odoratum. Reducing sugars were moderately present in $T$. vogelii, $A$. melegueta and $O$. gratissimum and slightly present in A. indica and E. odoratum while absent in L. camara. Furthermore, steroids were found in abundant in A. melegueta and high in $T$. vogelii while slightly present in A. indica, L. camara, E. odoratum and O. gratissimum. Resins were found in very low concentrations in all the tested plants and completely absent in T. vogelii while Acidic compounds were found in low concentrations in L. camara, E. odoratum and completely absent in other tested plants (Table 1).

The insecticidal plants and synthetic insecticide were found to have effects on oviposition and development of the bruchid ( $C$. serratus) on groundnut. The results showed that $A$. indica, A. melegueta, O. gratissimum and Cypermethrin, were the most effective insecticides which were significantly $(\mathrm{P}<0.05)$ different from other treatment and the control which recorded the highest mean number of 50.10 eggs. E. odoratum, L. camara and T. vogelli with mean numbers of 8.45, 5.20, and 5.20 were significantly $(\mathrm{P}<0.05)$ different from the control where no insecticide was applied. Similar trend was observed in the mean number of eggs hatched with control having the highest number of 42.8 eggs hatched and the least recorded in $A$. indica, A. melegueta, O. gratissimum and Cypermathrin (Table 2). All the bruchid exposed to Cypermathrin had 100 percent mortality at 18 hours after application which was not significantly different from A. indica A. melegueta, O. gratissimum. Eupatorium odoratum 
Table 1. Phytochemical Compositions of the Biopesticidal Plants

\begin{tabular}{lllllll}
\hline Parameters & $\begin{array}{l}\text { Azadirachta } \\
\text { indica }\end{array}$ & $\begin{array}{l}\text { Lantana } \\
\text { camara }\end{array}$ & $\begin{array}{l}\text { Eupatorium } \\
\text { odoratum }\end{array}$ & $\begin{array}{l}\text { Tephrosia } \\
\text { vogelii }\end{array}$ & $\begin{array}{l}\text { Afromomum } \\
\text { melegueta }\end{array}$ & $\begin{array}{l}\text { Ocimum } \\
\text { gratissimum }\end{array}$ \\
\hline Alkaloids & + & +++ & + & ++ & +++ & + \\
Glycosides & +++ & + & + & ++ & +++ & ++++ \\
Saponins & ++ & ++ & +++ & +++ & ++++ & +++ \\
$\begin{array}{l}\text { Reducing } \\
\text { sugar }\end{array}$ & + & - & + & ++ & ++ & ++ \\
Tannins & ++ & ++ & ++ & +++ & ++++ & ++ \\
Steroids & + & + & + & +++ & ++++ & + \\
Resins & + & + & + & - & + & + \\
$\begin{array}{l}\text { Acidic } \\
\text { compounds }\end{array}$ & - & + & + & - & - & - \\
\hline
\end{tabular}

$\mathbf{K E Y}+=$ slightly present,$++=$ moderately present,$+++=$ highly present,$++++=$ abundantly present, $-=$ absent

Table 2. Insecticidal effect of treatments on oviposition and development of Careydon serratus

Treatment No of eggs laid No of egg hatched $\quad$ No of dead bruchids

(Mean) (Mean) (Mean)
A. indica
$0.45 \pm 0.02 \mathrm{c}$
$0.11 \pm 0.74 \mathrm{c}$
$19.00 \pm 2.17 \mathrm{a}$
E. odoratum
$8.45 \pm 2.13 b$
$4.3 \pm 1.23 \mathrm{~b}$
$3.32 \pm 0.87 \mathrm{c}$
L .camara
$5.20 \pm 2.02 b$
$2.4 \pm 0.14 b$
$9.14 \pm 1.75 b$
$\mathrm{T}$. vogelii
$5.20 \pm 2.02 b$
$1.7 \pm 0.76 b$
$15.10 \pm 2.11 \mathrm{ab}$
A. melegueta
$0.45 \pm 0.02 \mathrm{c}$
$0.11 \pm 0.74 \mathrm{c}$
$19.00 \pm 2.17 \mathrm{a}$
O. gratissimum
$0.45 \pm 0.01 \mathrm{c}$
$0.11 \pm 0.74 \mathrm{c}$
$20.00 \pm 2.32 \mathrm{a}$
Cypermathrin
$0.45 \pm 0.01 \mathrm{c}$
$0.11 \pm 0.74 \mathrm{c}$
$20.00 \pm 2.32 \mathrm{a}$
Control
$50.10 \pm 4.45 \mathrm{a}$
$42.8 \pm 4.23 \mathrm{a}$
$1.00 \pm 0.02 \mathrm{c}$

Sample means followed by the same alphabets are not significantly different from each other (DMRT 0.05) 


\section{Macrothink}

Journal of Agricultural Studies

ISSN 2166-0379

2016, Vol. 4, No. 3

Table 3. Effect of insecticidal plants and synthetic insecticide on percent mortality of $C$. serratus

Mortality (hours)

\section{Powder}

A. indica

E. odoratum

L. camara

T.vogelli

A. melegueta

O. gratissimum

Cypermathrin

Control

\section{0}

10

35

44

50

50

80

0

12

65

20

50

60

68

78

95

0
18

98

40

70

70

98

99

100

0
24

100

50

85

80

100

100

100

recorded 50 percent mortality at 24 hours after application which was the least efficacious. Lantana camara and $T$. vogelli recorded were effective at 24 hours after application recording 80 and 85 percent respectively. Control experiment had the least percent mortality (5\%) after 24 hours while E. odoratum recorded $50 \%$ mortality after 24 hours of introduction of the bruchids (Table 3 ).

A significantly higher developmental period 23.2 days was recorded in E. odoratum and control experiment compared with $L$. camara and T. vogelli with developmental periods of 19.2 and 18.3 days respectively. The result showed a non-significant $(\mathrm{P}>0.05)$ effect on the sex ratio with males and females having similar result (Table 4). Table 5 shows the result of percentage germination of groundnut treated with the various insecticides. An average of 97\% germination was recorded from Cypermathrin, A. indica, A. melegueta, O. gratissimum, L. camara and T. vogelli treated seeds while $65 \%$ was recorded from E. odoratum treated seeds and the control experiment respectively

\section{Discussion}

Long term use of synthetic insecticides have culminated into serious health and environmental issues (Nathan and Kalaivani, 2006) which redirect the researchers to look for some safer alternatives and ecologically acceptable pesticides with no or less residual effect and resistance development property, for the control of important insect pests. The results of the present study indicate that, A. indica, A. melegueta, O. gratissimum, L. camara and T. vogelli can be used successfully against groundnut bruchid. 
Table 4. Insecticidal effect of treatments on developmental period and sex ratio of Careydon serratus on groundnut seeds

\begin{tabular}{lclll} 
Treatment & $\begin{array}{l}\text { Eggs laid (X) } \\
(\text { Male : Fem) }\end{array}$ & $\begin{array}{l}\text { No of adult (X) } \\
\text { emergence }\end{array}$ & $\begin{array}{l}\text { Developmental } \\
\text { period (days) }\end{array}$ & $\begin{array}{l}\text { Sex Ratio } \\
(\mathrm{M}: \mathrm{F})\end{array}$ \\
\hline & & & & \\
A. indica & $0.45 \pm 0.02^{\mathrm{c}}$ & $0.00 \pm 0.00^{\mathrm{c}}$ & $0.00 \pm 0.00^{\mathrm{c}}$ & $1: 0$ \\
E. odoratum & $8.45 \pm 2.13^{\mathrm{b}}$ & $7.11 \pm 1.23^{\mathrm{b}}$ & $23.2 \pm 3.23^{\mathrm{a}}$ & $5: 4$ \\
L.camara & $5.20 \pm 2.02^{\mathrm{b}}$ & $5.11 \pm 0.24^{\mathrm{b}}$ & $19.2 \pm 1.68^{\mathrm{b}}$ & $3: 3$ \\
T. vogelii & $6.16 \pm 1.45^{\mathrm{b}}$ & $5.23 \pm 1.12^{\mathrm{b}}$ & $18.3 \pm 2.14^{\mathrm{b}}$ & $4: 4$ \\
A. melegueta & $0.45 \pm 0.01^{\mathrm{c}}$ & $0.00 \pm 0.00^{\mathrm{c}}$ & $0.00 \pm 0.00^{\mathrm{c}}$ & $0: 0$ \\
O. gratissimum & $0.45 \pm 0.01^{\mathrm{c}}$ & $0.00 \pm 0.00^{\mathrm{c}}$ & $0.00 \pm 0.00^{\mathrm{c}}$ & $0: 0$ \\
Cypermathrin & $0.45 \pm 0.01^{\mathrm{c}}$ & $0.00 \pm 0.00^{\mathrm{c}}$ & $0.00 \pm 0.00^{\mathrm{c}}$ & $0: 0$ \\
Control & $50.10 \pm 4.45^{\mathrm{a}}$ & $50.32 \pm \pm 7.23^{\mathrm{a}}$ & $23.2 \pm 4.15^{\mathrm{a}}$ & $10: 9$ \\
\hline
\end{tabular}

Sample means followed by the same alphabets are not significantly different from each other (DMRT 0.05)

Table 5. Effect of plant powders and synthetic insecticide on germination percentage.

\begin{tabular}{llll}
\hline & & & \\
Treatment & 5 DAT & 7 DAT & 10 DAT \\
\hline A. indica & $75 \pm 5.54 \mathrm{a}$ & $98 \pm 6.65 \mathrm{a}$ & $98 \pm 6.65 \mathrm{a}$ \\
E. odoratum & $60 \pm 3.22 \mathrm{~b}$ & $60 \pm 3.22 \mathrm{~b}$ & $65 \pm 4.34 \mathrm{~b}$ \\
L. camara & $78 \pm 6.66 \mathrm{a}$ & $97 \pm 6.54 \mathrm{a}$ & $97 \pm 6.54 \mathrm{a}$ \\
T. vogelii & $77 \pm 4.74 \mathrm{a}$ & $97 \pm 6.54 \mathrm{a}$ & $97 \pm 6.54 \mathrm{a}$ \\
A. melegueta & $80 \pm 3.58 \mathrm{a}$ & $95 \pm 6.00 \mathrm{a}$ & $99 \pm 6.14 \mathrm{a}$ \\
O. gratissimum & $76 \pm 3.12 \mathrm{a}$ & $97 \pm 6.54 \mathrm{a}$ & $99 \pm 6.54 \mathrm{a}$ \\
Cypermathrin & $70 \pm 3.7 \mathrm{ab}$ & $95 \pm 4.40 \mathrm{a}$ & $95 \pm 4.40 \mathrm{a}$ \\
Control & $60 \pm 3.22 \mathrm{~b}$ & $65 \pm 3.30 \mathrm{~b}$ & $65 \pm 3.30 \mathrm{~b}$ \\
\hline
\end{tabular}

Sample means followed by the same alphabets are not significantly different from each other (DMRT 0.05)

Of the six insecticidal plants used for the protection of stored groundnuts, E. odoratum was less effective on the survival of $C$. serratus adults. The reason why the plant is used in spite of their lack of effectiveness is not clear. Their common feature is a strong smell, which is believed to repel or kill insects, but this is obviously not always the case. However, Shivan et. al., (2009) had reported a significant population and damage by $H$. amigera on cabbage in E. odoratum treated plants compared with $L$. camara and $T$. vogelli recording lower population of same pest. Neem extracts and neem based insecticides are reported effective on 
a wide range of insect pests on field crops (Baidoo et al., 2006, Okweche, et. al., 2013). The use of compounds such as neem (Azardiractha indica) extract or extract from $T$. vogelii has been attempted in stem-borer in Africa and elsewhere (Ploaszek, 1998). It has been reported that, several centuries before synthetic insecticide became available, farmers in India protected their crops with natural insecticides found in neem fruits and leaves (Polaszek, 1998). The insecticidal properties of neem products as reported by many authors (Schmutterer, 1990; NRC, 1992; Emosairue and Ukeh, 1996) have therefore been confirmed in this study. Emosairue and Ukeh (1996) reported that the behavior of insect towards a neem- treated seeds is a manifestation of repellence and phagodeterrence due to antifeedant effects. Ukeh et al. (2007) reported that neem has high contact toxicity on insect pest resulting in complete death of the pests or rendering them inactive. Recently, evidences on neem efficacy on insect pests of cowpea and some other crops in Nigeria have mounted and many cowpea researchers have given useful information on the potentials of neem in insect pests control (Amatobi, 2000; Oparaeke, 2005).

The report on chemical constituents of $L$. camara showed that the plant contains some active ingredients known as terpenes which is effective against insect pest and mosquito larvae (Sarath, et. al., 2004; Adenikan, 2013). Powders or extracts of T. vogelii, A. indica and L. camara have been shown in the past to be toxic to insects to insects such as Callosobruchus maculatus (Ukeh, et al. 2009), maize stem borers (Okweche, et. al 2013). It was considered at that time that $T$. vogelii itself had a potential as an economic source of rotenone, however, the rapid development of the chemical industry interrupted the spread of insecticides of vegetable origin (Golob et al., 1999). The nature of the active compound of T. vogelii, A. indica and L. camara, which could possibly be the one responsible for its anthelmintic properties, will be the subject of further investigation by the authors. Its mode of action, persistence and spectrum of activity against other stored products insects, as well as the optimal size of particles and level of application necessary to afford complete protection of stored grain, will also be determined.

The effectiveness of A. melegueta and O. gratissimum in causing mortality could be attributed to the presence of essential oils in the leaves and stems (Afolabi et al., 2007). The phytochemical analysis of the six biopesticides used revealed that they contained terpineol, alkaloids, glycosides, steroids, flavonoid as active ingredients. The active ingredients may be responsible for the noticed biopesticidal effectiveness. This finding is in line with that of Eke et al. (2013) that aromatic compound such as terpineol, glycosides, saponin and flavonoid has ovicidal, toxic and deterrent effects on stored product coleopterans. Out the six species of plant used against the bruchid, the extract of three plants (A. indica, T. vogelii, L. camara, A. melegueta and $O$. gratissimum) could induce mortality of $C$. serratus. It is doubtless that these plants will provide eco-friendly compounds for vectors control as these plants are widely used as spice and in therapeutics, it will not cause any harm to the flora and fauna. These plant products matched the efficacy of Cypermathrin whose undesirable side effects emanating from its use pose problems to the human environment and danger of mammalian toxicity; hence, A. indica, T. vogelii, L. camara, A. melegueta and $O$. gratissimum are recommended to farmers for the preservation of groundnut seeds against infestation of 
bruchid beetles during storage. The practice of mixing plants or parts of plants to stored grain appears to be more a token of allegiance to tradition than an effective control measure.

\section{References}

Afolabi C. A., Ibukun E. O., Afor, E., Obuotor, E. M., \& Farombi, E. O. (2007). Phytochemical constituent and antioxidant activity of extract from the leaves of Ocimum gratissimum. Sci. Res. Essay 2:163-166.

Alabi, O.Y., Odebiyi, J. A., \& Jackai, L. E. N. (2003). Field evaluation of cowpea cultivars (Vignaunguiculata (L) Walp.) for resistance to flower bud thrips (Megalurothrips sjostedti Trybom) Thysanoptera: Thripidae) International Journal of Pest Management, 49 (4), 287- 291. http://dx.doi.org/10.1080/0967087031000123706

Amatobi, C. I. (2000). Cashew plant extract as a promising aphicide in cowpea insect pest management. Abstracts of paper and poster presentations.World Cowpea Res. Conf.111. IITA-Ibadan, Nigeria, p.11.

Baidoo, P. K. Adam J. I., \& Sarpong-Nsiah, M. (2006). The role of extracts of Azadirachtaindica (A. Juss) and Lantana camara (L) in the reduction of damage done to maize plants by Lepidopterous stem-borers. International Journal of Food and Agricultural Research, 3(1), 66-70

Dansi L, Van Velson F. L., \& Vander Heuden C. A (1984). Methyl bromide: carcinogenic effects in the rat fore stomach. Toxicol. Appl. Pharmacol. 72, 262-271

Eke, F. N.; Onah, I. E.; Atama, C. F.; Ivoke, N., \& Eyo, J. E. (2013). Effectiveness of botanical powders against Callosobruchus maculatus (Coleoptera: Bruchidae) in some stored leguminous grains under laboratory conditions. African Journal of Biotechnology, 12(12), 1384-1391

Emosairue, S. O. \& Ukeh, D. A. (1996).Field trials of Neem products for the control of okra flea beetles (Podagrica sp.) in South-Eastern Nigeria. African Journal of Plant Protection, 37, $22-26$.

Emosairue, S. O.; Nwofia, G. E., \&Umuetok. S.B.A. (2004). Observation on the Insect complex associated with cowpea (Vigna unguiculata) (L.) Walp in Umudike,South- eastern. Nigeria Journal of Sustainable Agricultural Environment, 6(1), 38-43.

Golob, P. et al. (1999), The Use of Spices and Medicinals as Bioactive Protectants for Grains. Rome: Food and Agriculture Organization of the United Nations. Retrieved August9, 2006, from http://www.fao.org/docrep/x2230e/x2230e11.htm

Harbone J. B (1973). Phytochemicals Methods. London: Chapman and Hall.

Mahdi S. H. A., \& Rahman, M. K (2008). Insecticidal effect of some spices on Callosobruchus maculatus (Fabricius) in black gram seeds. Univ. J. Zool. Rajshahi Univ, 27, 47-50.

Nathan, S. S., \& Kalaivani, K. (2006). Combined effects of azadirachtin and 
nucleopolyhedrovirus (SpltNPV) on Spodoptera litura Fabricius (Lepidoptera: Noctuidae) larvae. Biological Control, 39, 96-104.

Okigbo, B. N. (1978). Grain legumes in the agriculture of the tropics. In Pests of Grain legumes Ecology and control (Edited by Singh S.R. Van emden H.E. and Taylor T.A) Academic Press, Inc., New York.

Okweche, S. I, Ukeh D. A., \& Udo, I. A. (2013) Comparative efficacy of pesticidal plant products and Carbofuran in the management of maize stem borers in Nigeria. Biopesticide International, 9(1), 23-30.

Omongo, C. A., Adipala, E., Ogenga Latigo, M. W., \& Kyamanywa, S. (1997). Insecticide application to reduce pest infestation and damage on cowpea in Uganda. African Journal of Plant Protection, 4(2), 91-100.

Oparaeke, A. M. (2005). Studies on insecticidal potential of extracts of Gmelina arboreaproductsfor control of field pests of cowpea, Vigna unguiculata (L) Walp. The pod borer Maruca vitrata and the coreid bug, Clavigralla tomentosicollis. Journal of Plant Protection Research, 4 (1).

Ousman A, Ngassoum M. B, Essia-Ngang J. J., Ngamo L. S. T., \& Ndjouenke, R. (2007). Insecticidal activity of spicy plant oils against Sitophilus zeamais in stored maize in Cameroon. Agric. J. 2:192-196.

Polaszek, A. (1998). African Cereal Stem Borers: Economic Importance, Taxonomy, Natural Enemies and Control. Wallingford, UK: CABI, 530.

Rajapakse, R. H. S., \& Disna R. (2009). Pesticidal potential of some selected tropical plant extracts against Callosobruchus maculates (F) and Callosobruchus chinensis (L) (Coleptera: Bruchidae).Tropical Agricultural Research and Extension, Sri Lanka, 11.

Rajapakse, R. H. S., Rajapakse, H. L. de Z., \& Disna R. , (2002). Effect of botanicals on oviposition, hatchability and mortality of Callosobruchus maculates L. Entomon, 27(1), 93-98.

Sarath, M., Varun, N., \& Minija, J. (2004).Herbal larvicides to controlmosquito larvae. Natural Product Radiance, 3(1) 24-26.

Schmutterer, H. (1990). Properties and potential of natural pesticides from the Neem tree, Azadirachta indica. Annual Review of Entomology, 35, 271-97.

Shivan R. Y., \& Sachinkumar R. P. (2009) Field efficacy of plant extracts on larval populations of PlutellaxylostellaL.and Helicoverpa armigera Hub. and their impact on cabbage infestation. Journal of Biopesticides, 2(1), 32-36.

Ukeh, D. A, Birkett, M. A., Bruce, T. J. A., Allan, E. J, Pickett, J. A., \& Mordue, A . J. (2009). Behavioural responses of the maize weevil, Sitophilus zeamais, to host (stored-grain) andnonhost plant volatiles. Journal of Pest Management, 66(1), 44-50.

Ukeh, D. A., Emosairue, S. O., Udo I. A., \& Ofem, U. A. (2007).Field Evaluation of Neem 


\section{Macrothink}

Journal of Agricultural Studies ISSN 2166-0379

(Azardirachta indica A. Juss) products for the management of lepidopterous stem borer of maize (Zea mays L.) in Calabar, Nigeria. Research Journal of Applied Science (Medwell) 2(6) 653-658.

\section{Copyright Disclaimer}

Copyright for this article is retained by the author(s), with first publication rights granted to the journal.

This is an open-access article distributed under the terms and conditions of the Creative Commons Attribution license (http://creativecommons.org/licenses/by/3.0/). 